\title{
PARTISIPASI SISWA TERHADAP OLAHRAGA MASKULIN DI KABUPATEN CIREBON
}

\author{
Didik Subhakti Prawira Raharja ${ }^{1}$ dan Ananda Febrianty ${ }^{2}$ \\ Universitas Majalengka, Indonesia \\ didikspraharja@unma.ac.id
}

\begin{abstract}
ABSTRAK. Tujuan dari penelitian ini adalah untuk mengetahui angka partisipasi siswi terhadap olahraga maskulin di kabupaten Cirebon. Metode yang digunakan dalam penelitian ini adalah metode survai. Populasi dalam penelitian ini adalah 1505 orang siswa SLTP sederajat di Kecamatan Karangsembung kabupaten Cirebon. Jenis data yang digunakan adalah data primer yang diperoleh dari kuesioner dan hasil perhitungan instrumen burupa angket partisipasi. Hasil menunjukkan siswa yang menyukai olahraga maskulin sebanyak 38\% atau 573 siswa, melakukan kegiatan olahraga 1x dalam 1 minggu 54\% atau 308 orang siswi, yang melakukan kegiatan $2 x$ dalam 1 minggu hanya $5 \%$ atau 31 orang sedangkan yang melakukan kegiatan 3x dalam 1 minggu adalah $41 \%$ atau 234 orang siswi dan siswa yang berpartisipasi aktif dalam olahraga maskulin hanya $8 \%$ dari populasi. Kesimpulan dari penelitian ini adalah olahraga maskulin masih belum menjadi pilihan yang dominan diminati oleh siswa di kecamatan karangsembung. Dengan demikian perlu adanya kebijakan dan dorongan agar tingkat partisipasinya meningkat dan dapat mengoptimalkan para partisipan untuk terus dipertahankan dan berprestasi.
\end{abstract}

Kata Kunci: Partisipasi; olahraga maskulin

\section{Pendahuluan}

Wanita pertama kali dimasukkan untuk kompetisi atletik di Olimpiade pada tahun 1928. Pada tahun itu proporsi wanita di antara kontestan Olimpiade adalah 9,6\%. Pada tahun 2004, persentase atlet wanita meningkat menjadi 40,7\%. (Pfister, 2010). Sejalan dengan itu perbedaan dalam partisipasi olahraga antara jenis kelamin terus menurun, di Denmark $46 \%$ dari pria dan 37\% dari populasi wanita (Pfister, 2010). Bahkan Dalam beberapa dasawarsa terakhir terjadi peningkatan partisipasi wanita dalam olahraga kompetitif (Golden, 2002).

Berdasarkan hasil Asian Games 2018 hasil perolehan mendali Indonesia berasal dari atlet wanita diantaranya seperti Defia Rosmaniar cabang tekwondo, lalu ada Aries Susanti Rahayu cabang panjat tebing, Puspa Arumsari cabang pencak silat, Sarah Tria Monita cabang pencak silat, wanita mulai bisa menyetarakan dirinya dan adanya ajang-ajang untuk mengukur tingkat prestasi dalam bidang olahraga baik amatir maupun tingkat profesional. Sehingga dari sini di butuhkan sekali atlet-atlet wanita untuk bisa bersaing dan membuktikan bahwa wanita bisa berolahraga dan berprestasi bahkan melebihi laki-laki sehingga dalam kenyataan nya wanita harus juga berpartisipasi dalam dunia olahraga. Undang-Undang Republik Indonesia No 3 Thn 2005 Pasal 6 Bab IV tentang Sistem Keolahragaan Nasional (SKN) yang 
menegaskan mengenai hak yang sama bagi setiap warga negara untuk berolahraga, serta memperoleh pelayanan sesuai dengan kemampuan dalam kegiatan olahraga.

Keberhasilan olahraga dapat dilihat dari Sport Development Index (SDI) dalam Mutohir dan Maksum (2007) ada beberapa indikator yang menjadi dasar maju atau mundurnya masyarakat. Indikator-indikator tersebut meliputi: partisipasi (participation), ruang terbuka (open space), kebugaran jasmani (physical fitness) dan sumber daya manusia (human resources).Dengan demikian salah satu upaya dalam meningkatkan keberhasilan dalam olahraga salah satu peluang yang dapat di manfaatkan adalah dengan meningkatkan partisipasi wanita dalam berolahraga.

Supriyanto (2018). 'Olahraga maskulin adalah olahraga yang mempunyai karakter diantaranya menghindari sifat kewanitaan, membatasi emosi, ambisius, mandiri, kuat dan agresif serta bisa dikatakan olahraga keras'. Soekanto dalam Nurasa (2010), mengartikan partisipasi sebagai peran serta, yaitu setiap proses identifikasi atau menjadi peserta suatu proses komunikasi atau kegiatan Bersama dalam situasi social tertentu. Sedangkan Almound dan Bringham dalam Nurasa (2010) mendefinisikan partisipasi adalah orang-orang yang orientasinya justru pada penyusunan dan tuntutan kebutuhan dan dalam pembuatan keputusan.

Hamijoyo (1974) menjelaskan bahwa jenis-jenis partisipasi dapat dibedakan menjadi 5 bagian, yaitu: partisipasi berupa buah pikiran, partisipasi berupa tenaga, partisipasi berupa harta benda, partisipasi berupa keterampilan atau kemahiran, partisipasi berupa sosial.

\section{Metode Penelitian (12 pt)}

Ali (2010) mengungkapkan survei pada dasarnya merupakan pemeriksaan secara teliti tentang fakta atau fenomena prilaku dan sosial terhadap subjek dalam jumlah besar, survey bukan semata-mata dilakukan untuk mengumpulkan data atau informasi, seperti pendapat atau sikap, tetapi juga membuat deskripsi komprehensif maupun untuk menjelaskan hubungan antar berbagai variable yang diteliti. Lebih lanjut Ali (2010) maksud utama dilakukannya survei adalah :

1. Untuk memperoleh penjelasan komprehensif tentang fenomena tertentu, termasuk keterkaitan antar berbagai variabelnya.

2. Untuk dijadikan dasar dalam melakukan analisis pertumbuhan.

3. Untuk dijadikan dasar dalam melakukan analisis kecenderungan.

Instrument yang digunakan adalah angket merujuk pada kuisioner partisipasi dalam sports development indeks (2007). Dan pengolahan data menggunakan statiktik deskriptif yang hanya mempersentasikan data yang terkumpul. 


\section{Hasil Penelitian dan Pembahasan}

Data yang diperoleh adalah sesuai dengan jawaban responden atas pertanyaan yang ada dalam kuesioner/angket dalam instrument penelitiandapat dilihat pada tabel 1 sebagai berikut:

Tabel 1

data hasil perhitungan angket berdasarkan pilihan partisipan

\begin{tabular}{|c|c|c|c|}
\hline No & Nama Cabang OR & Jumlah Siswi & $\%$ dari 1505 Siswi \\
\hline 1 & Bola basket & 201 & $13 \%$ \\
\hline 2 & Bola voli & 131 & $9 \%$ \\
\hline 3 & Sepak bola & 47 & $3 \%$ \\
\hline 4 & Futsal & 111 & $7 \%$ \\
\hline 5 & Pancak silat & 60 & $4 \%$ \\
\hline 6 & Tekwondo & 23 & $2 \%$ \\
\hline 7 & Lari & 296 & $20 \%$ \\
\hline 8 & Atletik & 101 & $7 \%$ \\
\hline 9 & Bulu tangkis & 124 & $8 \%$ \\
\hline 10 & Renang & 63 & $4 \%$ \\
\hline 11 & Kasti & 51 & $3 \%$ \\
\hline 12 & Senam Aerobik & 55 & $4 \%$ \\
\hline 13 & Tidak berminat & 112 & $7 \%$ \\
\hline 14 & Angket tidak kembali & 48 & $3 \%$ \\
\hline 15 & Tidak masuk absen & 61 & $4 \%$ \\
\hline 16 & Tidak mengisi angket & 21 & $2 \%$ \\
\hline \multicolumn{2}{|r|}{ Total } & 1505 & $100 \%$ \\
\hline
\end{tabular}

Sumber: hasil perhitungan angket

Data menunjukan siswa perempuan yang memilih tidak menyukai olahraga dengan alasan yang telah di tulis di dalam angket lebih tidak tertarik terhadap kegiatan olahraga dan lebih memilih untuk mengikuti kegiatan seperti kesenian, paskibra, pramuka dan ekstrakulikuler yang lainnya sebanyak 112 orang atau $7 \%$ dari populasi, angket tidak kembali sebanyak 48 orang dikarenakan pada saat peneliti membagikan angket jumlah tidak sama dengan populasi, alpa,ijin, sakit, dispensasi atau tidak masuk sekolah pada saat peneliti membagikan angket sebanyak 61 orang atau 4\% dari populasi, tidak mengisi angket sebesar 1 $\%$ dari populasi atau 21 orang, dilihat dari jenis olahraga yang diminati dan disukai responden lebih tertarik pada olahraga-olahraga yang tidak termasuk maskulin yang ditunjukan no 7 sampai no 12 Tabel yang berwarna biru dalam Tabel 1 sebanyak 690 orang atau $46 \%$ memilih menyukai olahraga seperti lari, atletik, bulu tangkis, renang, kasti dan senam aerobik dan hanya beberapa yang berpartisipasi di dalamnya dan mengikuti pelatihan di luar jam sekolah hanya 1 minggu sekali. 
Tabel 2

Data hasil perhitungan angket olahraga maskulin

\begin{tabular}{|c|l|c|c|}
\hline No & Nama Cabang OR & Jumlah Siswi & $\%$ dari 573 Siswi \\
\hline 1 & Bola basket & 201 & $35 \%$ \\
\hline 2 & Bola voly & 131 & $23 \%$ \\
\hline 3 & Sepak bola & 47 & $8 \%$ \\
\hline 4 & Futsal & 111 & $19 \%$ \\
\hline 5 & Pancak silat & 60 & $10 \%$ \\
\hline 6 & Tekwondo & 23 & $4 \%$ \\
\hline & Total Siswi & 573 & $100 \%$ \\
\hline
\end{tabular}

Tabel 2 medeskripsikan sebaran tingkat partisipasi siswa dalam olahraga maskulin ditinjau dari jenis olahraga yang partisipan pilih. Data menunjukkan bahwa olahraga bola basket menjadi yang terbanyak di pilih, hal tersebut dikarenkan olahraga bola basket lebih popular di daerah tersebut.

Tabel 3

Data hasil perhitungan angket dengan aktivitas 1 kali dalam seminggu

\begin{tabular}{|c|l|c|c|c|c|}
\hline No & Nama Cabang OR & $\begin{array}{c}\text { Jumlah } \\
\text { Siswi }\end{array}$ & $\begin{array}{c}\% \text { dari 573 } \\
\text { Siswi }\end{array}$ & $\begin{array}{c}\text { Tigkat Partisipasi dalam 1 x } \\
\text { dalam 1 Minggu \% dari 308 } \\
\text { orang siswi }\end{array}$ \\
\hline 1 & Bola basket & 201 & $35 \%$ & 125 & $41 \%$ \\
\hline 2 & Bola voly & 131 & $23 \%$ & 67 & $21 \%$ \\
\hline 3 & Sepak bola & 47 & $8 \%$ & 33 & $11 \%$ \\
\hline 4 & Futsal & 111 & $19 \%$ & 61 & $20 \%$ \\
\hline 5 & Pancak silat & 60 & $10 \%$ & 9 & $3 \%$ \\
\hline 6 & Tekwondo & 23 & $4 \%$ & 13 & $4 \%$ \\
\hline \multicolumn{2}{|l|}{ Total Siswi } & 573 & $100 \%$ & 308 & $100 \%$ \\
\hline
\end{tabular}

Seperti yang telah dijelaskan dalam mengetahui tinggat pertisipasi siswi dalam melakukan kegiatan olahraga dalam jangka waktu 1 minggu terakhir di katakan berpartisipasi menurut perhitungan index partisipasi dalam (Mutohir \& Maksum, 2007) dalam penelitian terkait Aamerican College of Sport Medicin merekomendasikan bahwa partisipasi olahraga yang ideal (dianggap aktif) berkisar anatara 3-5 kali pertemuan dalam 1 minggu.

Tabel 4

Data hasil perhitungan angket dengan aktivitas 2 kali dalam seminggu

\begin{tabular}{|c|l|c|c|c|c|}
\hline No & Nama Cabang OR & $\begin{array}{c}\text { Jumlah } \\
\text { Siswi }\end{array}$ & \% dari 573 Siswi & \multicolumn{2}{|c|}{$\begin{array}{c}\text { Tigkat Partisipasi dalam 2 } \\
\text { x dalam 1 Minggu \% dari } \\
\text { 31 orang siswi }\end{array}$} \\
\hline 1 & Bola basket & 201 & $35 \%$ & 11 & $35 \%$ \\
\hline 2 & Bola voly & 131 & $23 \%$ & 8 & $26 \%$ \\
\hline
\end{tabular}




\begin{tabular}{|c|l|c|c|c|c|}
\hline 3 & Sepak bola & 47 & $8 \%$ & 0 & $0 \%$ \\
\hline 4 & Futsal & 111 & $19 \%$ & 8 & $26 \%$ \\
\hline 5 & Pancak silat & 60 & $10 \%$ & 4 & $13 \%$ \\
\hline 6 & Tekwondo & 23 & $4 \%$ & 0 & $0 \%$ \\
\hline \multicolumn{2}{|l}{ Total Siswi } & 573 & $100 \%$ & 31 & $100 \%$ \\
\hline
\end{tabular}

Berdasarkan dari pengelompokkan data aktivitasnya, siswa yang memilih olahraga maskulin dengan aktivitas 2 kali dalam seminggu cenderung lebih kecil angka persentasinya, hal ini di sebabkan dari banyaknya kegiantan yang di ikuti sehingga anak melakukan aktivitas hanya diwaktu senggang saja meskipun jadwal latihannya sudah terjadwal.

Tabel 5

Data hasil perhitungan angket dengan aktivitas 3 kali dalam seminggu

\begin{tabular}{|c|l|c|c|c|c|}
\hline No & Nama Cabang OR & $\begin{array}{c}\text { Jumlah } \\
\text { Siswi }\end{array}$ & $\begin{array}{c}\% \text { dari 573 } \\
\text { Siswi }\end{array}$ & $\begin{array}{c}\text { Tigkat Partisipasi dalam 3 } \\
\text { x dalam 1 Minggu \% dari } \\
\text { 234 orang siswi }\end{array}$ \\
\hline 1 & Bola basket & 201 & $35 \%$ & 65 & $28 \%$ \\
\hline 2 & Bola voly & 131 & $23 \%$ & 56 & $24 \%$ \\
\hline 3 & Sepak bola & 47 & $8 \%$ & 14 & $6 \%$ \\
\hline 4 & Futsal & 111 & $19 \%$ & 42 & $18 \%$ \\
\hline 5 & Pancak silat & 60 & $10 \%$ & 47 & $20 \%$ \\
\hline 6 & Tekwondo & 23 & $4 \%$ & 10 & $4 \%$ \\
\hline & Total Siswi & 573 & $100 \%$ & 234 & $100 \%$ \\
\hline
\end{tabular}

Setiap orang yang berolahraga tidak memiliki tujuan yang sama dalam hal ini berkaitan dengan prestasi olahraga siswa yang berperan aktif lebih memiliki peluang besar untuk memperoleh prestasi dalam bidang olahraga. dalam hal ini siswa yang beraktivitas 3 kali dalam seminggu tentu memiliki kemampuan lebih dibandingkan dengan siswa yang aktivitasnya hanya 1 kali atau 2 kali dalam seminggu, sehingga pada tahap ini diperlukan perhatian khusus untuk dapat meningkatkan prestasinya.

\section{Kesimpulan}

Berdasarkan hasil pengolahan dan analisis data dapat disimpulkan bahwa olahraga maskulin masih belum menjadi pilihan yang dominan diminati oleh siswa di kecamatan karangsembung. Dengan demikian perlu adanya kebijakan dan dorongan agar tingkat partisipasi meningkat dan dapat mengoptimalkan para partisipan untuk terus dipertahankan dan berprestasi.

Kesenangan mengikuti olahraga maskulin dengan disertai data aktivitas melakukannya dalam seminggu menunjukkan adanya harapan yang dapat diciptakan mengingat besarnya 
angka persentase melakukan aktivitas 3 kali dalam seminggu, hal tersebut perlu dipertahankan dan ditingkatkan bagi siswa lain.

Mengingat adanya peluang dalam meningkatkan harkat dan martabat suatu bangsa melalui olahraga terlebih melalui olahraga maskulin, sehingga perlu adanya perhatian khusus dalam proses pembinaannya yang sejalan dengan emansipasi wanita dan jaminan dari undangundang.

Keterbatasan dari penelitian ini adalah tempat dan sampel penelitian yang terbatas, tentunya diharapkan banyak penelitian-penelitian serupa yang dapat menggambarkan tempat dan populasi yang lebih luas dengan berbagai tingkatan dan usia

\section{Daftar Pustaka(11 pt)}

Ali, Mohammad. (2010). Metodologi dan Aplikasi, Riset Pendidikan. Bandung: CV Pustaka Cendikia Golden, N.H, 2002, A Review of The Female Athlete Triad, International Journal Adolescent Medicine, $14: 1$.

Hamijoyo. (1974). Partisipasi dalam Pembangungan. Jakarta: Depdikbud.

Nurasa, Heru. (2010). Reformasi Administrasi dan Partisipasi Masyarakat. (perspektif Teori dan Praktik dalam Pembangunan Pedesaan). Bandung: UNPAD Press

Supriyanto, Agus. 2008. Pembentukan Karakter Olahragawan Ditinjau Dari Perbedaan Gender, Peran Serta Orangtua, Guru, Pelatih Olahraga Dan Keikutsertaan Dalam Aktivitas Olahraga Serta Jenis Olahraganya.Makalah seminar olahragaNasional ke II. 1-25.

Toho Cholik Mutohir dan Ali Maksum. (2007). Sport Development Index. Jakarta: PT. Indeks.

Pfister, G. (2010). Women in sport-gender relations and future perspectives. Sport in Society, 13(2), 234-248. https://doi.org/10.1080/17430430903522954 